\title{
Nutrition and immunity in the elderly
}

\author{
Bruno Lesourd* and Lynda Mazari \\ Unité de Médecine Nutritionnelle Gériatrique, Hôpital Charles Foix, 7 Avenue de la République, 94200 Ivry sur Seine, France
}

\begin{abstract}
Immune function declines with age, leading to increased infection and cancer rates in aged individuals. In fact, recent progress in the study of immune ageing has introduced the idea that rather than a general decline in the functions of the immune system with age, immune ageing is mainly characterized by a progressive appearance of immune dysregulation throughout life. Changes appear earlier in life for cell-mediated immunity than for humoral immunity. Thus, agerelated modifications in cell-mediated immunity, i.e. changes in naive:memory T-cells, mature: immature T-cells, T-helper 1:T-helper 2 cells are more important in the elderly than changes in humoral immunity, i.e. CD5 : CD5+ cells or length of antibody responses. Such evolution of the immune system has been linked to declining thymus function and to accumulative antigenic influence over the lifespan. In contrast, innate immunity (macrophage functions) is preserved or even increased during the ageing process. This finding shows that the 'primitive' immune system is less affected by the ageing process than the sophisticated specific immune system. The present review focuses on innate and cell-mediated immune changes with ageing. It provides evidence that primary changes (intrinsic modifications in the immune system) and secondary changes (resulting from environmental influences during the lifespan) exert different influences on the immune system. Primary changes, occurring in healthy individuals, seem less important nowadays than they were considered to be previously. For example, interleukin 2 secretion in some very healthy aged individuals is comparable with that in younger adults. Primary immune changes may not explain the increased incidence and severity of infections observed in the elderly population. Secondary immunological changes are far more frequent and are certainly responsible for most of the immune modifications observed in the elderly population. Environmental factors leading to secondary immune dysfunctions include not only antigenic influence, which is a reflection of diseases experienced over the lifespan, but also many other factors such as drug intake, physical activity and diet; factors for which important changes occur in the elderly population. Nutritional factors play a major role in the immune responses of aged individuals and the present review shows that nutritional influences on immune responses are of great consequence in aged individuals, even in the very healthy elderly.
\end{abstract}

Infection: Ageing: Immune system: Nutritional status

Age-related changes in the immune system have been the subject of investigation for several decades. There is obvious evidence, both from experimental and clinical data, that immune responses decline with the ageing process (Makinodan \& Kay, 1980; Miller, 1992). More recently, it was reported that some immune functions, such as interleukin (IL) 6 production, do not decrease but rather increase with age (Kubo \& Cinader, 1990; Erschler et al. 1993), leading to the new concept of age-related immune dysregulation (Kubo \& Cinader, 1990; Ben-Yehuda et al. 1994; Lesourd \& Meaume, 1994; Shearer, 1997).
Most investigations into immune ageing in human subjects rely on data from 'apparently healthy' aged individuals without checking for the possibility of underlying diseases, which may be clinically not apparent. Some studies have attempted to check for this confounding factor. Most studies have investigated individuals selected on the criteria of the SENIEUR protocol (Ligthart et al. 1984) of the European Community's Concerted Action Program on Ageing (EURAGE). This protocol established selection criteria for immunogerontological studies taking into account: 
(a) the living conditions of healthy volunteers;

(b) laboratory values for good health criteria;

(c) drug intake that may or may not be acceptable.

Some authors (Traill et al. 1985; Reibnegger et al. 1988), including our group (Lesourd et al. 1994; Mazari \& Lesourd, 1998) found that the SENIEUR criteria were not precise enough to exclude the possibility of clinically hidden ongoing disease and/or of nutritional deficiency or other environmental factors influencing immune responses. New exclusion criteria (Table 1 shows the criteria we have used; Lesourd et al. 1994) included several biological variables supporting the diagnosis of undiagnosed ongoing diseases such as diabetes, atherosclerosis, minor sequelae, from recent (few years) previous diseases (even after apparently complete recovery, since they may have pushed the elderly individual towards a stage of frailty not always easy to recognize), and the presence of nutritional deficits, including low levels of vitamins and/or trace elements. Adding new criteria for checking the health of the volunteers allowed these researchers to compare groups of 'very healthy individuals', who fitted all additional criteria, with groups they termed 'apparently-healthy elderly', who fitted the SENIEUR criteria. It is obvious from these studies as well as from other studies (Mysliwska et al. 1998) that health and nutritional factors may influence immune functions of aged individuals, even in apparently-healthy individuals.

It appears that borderline difficult-to-characterize secondary immune deficiencies are quite common in aged individuals, and that part of what has been described as immune ageing (primary immune deficiencies) may be in fact related to secondary immune deficiencies, in particular to undiagnosed diseases and to low nutritional status. The importance of nutritional factors within the secondary immune deficiencies of aged individuals should be emphasized, since they are common in the elderly population; for example, one-third of the home-living self-sufficient population studied in the EURONUT/Seneca European Reference Study on Nutrition and Ageing had a low serum level

Table 1. Criteria for the selection of very healthy elderly*

\begin{tabular}{|c|c|}
\hline $\begin{array}{l}\text { SENIEUR } \\
\text { criteria }\end{array}$ & $\begin{array}{l}\text { In good health } \\
\text { With no ongoing, developing or degenerative diseases } \\
\text { Normal adult values for laboratory variables } \\
\text { No drugs acting on the immune system }\end{array}$ \\
\hline $\begin{array}{l}2 \text { Additional } \\
\text { criteria }\end{array}$ & $\begin{array}{l}\text { No disease in the past } 5 \text { years } \\
\text { No motor skill difficulties } \\
\text { 'Normal' physical activity: }>4 \mathrm{~km} \text { walk/d } \\
\text { No drug treatment for cardiac, neurological or } \\
\text { psychotropical diseases (including depression) } \\
\text { 'Normal mental status' (Mini mental status of Folstein } \\
\geq 28 / 30 \text { ) } \\
\text { Serum albumin } \geq 39 \mathrm{~g} / \mathrm{l} \\
\text { No low values for trace elements }(\mathrm{Zn} \text { and } \mathrm{Se} \text { ) or } \\
\text { vitamins }\left(\mathrm{B}_{6} \text {, folate, } \mathrm{B}_{12}, \mathrm{~A} \text { and } \mathrm{C}\right)\end{array}$ \\
\hline
\end{tabular}

* We used the criteria of the SENIEUR protocol (Ligthart et al. 1984), to which we added health criteria for the previous 5 years (Lesourd et al. 1994; Lesourd \& Meaume, 1994) including drug intake and serum albumin $(>39 \mathrm{~g} / \mathrm{l})$. All subjects had normal values for serum or plasma trace element or vitamin levels tested; reference cut-off points used were those used in our laboratory together with EURONUT/Seneca values (Haller et al. 1996). for at least one vitamin (Haller et al. 1996), which may be responsible for lower immune responses. Such a distinction between primary and secondary immune deficiency is important in order to understand how the immune functions age in an irreversible (primary immune deficiency) or reversible (secondary immune deficiency) manner. Furthermore, it may facilitate an understanding of the major influence of secondary immune deficiency on the immune system of aged individuals, and perhaps, as in the case of nutritional deficiencies, treatment of aged individuals in order to reverse secondary immune deficiency. Such nutritional treatment, using trace element-vitamin supplementation, has been shown to be effective in improving the immune responses of aged individuals, not only in institutionalized aged patients (Boukaïba et al. 1993; Galan et al. 1997), but even in the self-sufficient home-living apparently-healthy elderly (for review, see Lesourd et al. 1998). This form of supplementation is effective not only because it induces increased immune responses in selfsufficient home-living apparently-healthy elderly subjects, but it has also been claimed that it may be clinically effective in reducing the number of infections over 1 year (Chandra, 1992a).

The present review will first describe immune ageing per $s e$, i.e. primary immune deficiency. Then we will focus on the influence of nutritional factors on immune ageing (secondary immune deficiency), showing that the immune deficiency observed in profoundly-undernourished elderly subjects may be present, to a lesser extent, in self-sufficient elderly subjects with micronutrient deficits. Finally, we will briefly focus on supplementation studies in healthy aged individuals in order to show that recommended dietary allowances (RDA) may be too low in the elderly, and that immune ageing, at least in human subjects, may be partly due to insufficient intakes in the general population. Adequate nutrition is an effective way, through energy restriction, to slow down the effect of age on the immune system in rodents (Venkatraman et al. 1994; Fernandes et al. 1991). Nutrition may also affect the human immune system of aged individuals from a different aspect, that of prevention and correction of nutritional deficit.

\section{Primary immune deficiency in the elderly}

In recent years numerous studies have investigated the agerelated changes in immune responses. The most important changes will be presented, focusing on the most striking feature: modifications in cell-mediated immunity (T-cell functions). The data presented come from our group and concern the 'very healthy elderly' and the 'apparentlyhealthy elderly' we have studied in the past year. Thus, these results strictly represent the primary and secondary immune deficiency associated with the ageing process.

\section{Decrease in new T lymphocyte generation}

Lymphocytes are generated in bone marrow and mature as T-cells in the thymus. The ability of stem cells to undergo clonal proliferation declines with age (Tyan, 1981), as does thymocyte maturation in relation to thymus involution (Steinmann et al. 1985; Hirokawa et al. 1994). In fact, 
thymus involution starts early in life and is greatly accelerated after the hormonal changes associated with puberty (Steinmann et al. 1985). Thymic tissue is progressively replaced by fat, and new T lymphocyte generation is almost absent in 60-year-old individuals. Thymus involution is probably of major significance during acute infections, since aged individuals do not replace the destroyed lymphocytes at the efficient levels observed for younger adults during lung infections (for review, see Lesourd, 1999).

\section{Changes in peripheral blood lymphocytes}

Lymphocyte numbers in peripheral blood decrease with age (Lesourd et al. 1994; Lesourd \& Meaume, 1994; Huppert et al. 1998), but this change remains of minor importance $(10-15 \%)$ in nonagenarians when they are very healthy (Mazari \& Lesourd, 1998), and may not be detectable at a younger age (Wick \& Grubeck-Lowensteins 1997), even though contradictory results have been published recently (Huppert et al. 1998). In addition, T lymphocyte subset equilibrium changes with age. The modification occurring earlier concerned naive:memory cells which is often measured in human subjects as CD45RA:CD45RD. This type of modification, related to antigenic exposure, starts in infancy, increases greatly during childhood and early adulthood until age 30 years, and continues thereafter but at a far lower rate until death (Cossarizza et al. 1992). The transformation of naive CD4+ T lymphocytes to memory CD4+ $\mathrm{T}$ lymphocytes has also been shown to be accelerated in aged mice (Thoman, 1997). The rapid change in naive: memory $\mathrm{T}$ lymphocytes in early adulthood is linked to new antigen exposure, and the later change (slow ratio changes in the elderly) probably, at least in part, to the ageing phenomenon (Thoman, 1997).

Aged individuals express fewer mature T-cells (CD3+) and higher numbers of immature T-cells (CD2+CD3-; Table 2). This change, detectable only after age 50 years, slowly increases thereafter, even in the very old (> 90 years; Huppert et al. 1998). As synthesis of CD2 and CD3 molecules occurs during thymic maturation, the decrease in mature:immature cells is certainly dependent on thymic involution. Nevertheless, thymic function remains at a sufficient level to permit generation of new CD3+ lymphocytes until mid-adulthood. When thymus maturation is almost non-existent, then the mature:immature $\mathrm{T}$-cell value in peripheral blood starts to decline. Very late in life, new $\mathrm{CD} 3+\mathrm{T}$ lymphocytes may be generated in other organs, probably in the liver. Indeed, this process has been demonstrated in old mice (Abo, 1992; Nakayama et al. 1994), and the same process probably occurs in man (Lesourd et al. 1994; Mazari \& Lesourd, 1998). Not only are immature T lymphocytes more numerous (in terms of percentage and absolute values; Lesourd et al. 1994; Mazari \& Lesourd, 1998), but in addition immature T lymphocytes are also less mature: the proportion of the CD2+CD4-CD8double negative population also increases in the very old (Mazari \& Lesourd, 1998). While mature:immature T lymphocytes decreases with age in old individuals, natural killer (NK) cells increase (Ligthart et al. 1986; AlèsMartinez et al. 1988), and these factors are highly correlated (Mazari \& Lesourd, 1998), even though it was claimed recently that levels of $\mathrm{CD} 57+$ cells remain constant (Huppert et al. 1998). Indeed, an increase in the NK population with age has been observed irrespective of the marker used to characterize NK cells, i.e. CD57+ cells (Ligthart et al. 1986; Lesourd \& Meaume, 1994; Mazari \& Lesourd, 1998), CD16+ cells (Goto \& Nishioka, 1989; Krishnaraj, 1997; Utsuyama et al. 1997) or NK function (Alès-Martinez et al. 1988; Krishnaraj, 1997), although other reports have claimed that there is no change (Wick \& GrubeckLowenstein, 1997; Huppert et al. 1998). The increases reported in NK were always associated with decreased $\mathrm{CD} 3+$ lymphocytes. In fact, the increase in immature CD2+CD3 - cells represents part of the increased NK population (Alès-Martinez et al. 1988; Lesourd \& Meaume, 1994).

Ageing is associated with a decrease in the CD8+ subset, but the CD4+ subset remains unchanged in very healthy elderly subjects (Lesourd et al. 1994; Lesourd \& Meaume, 1994; Wick \& Grubeck-Lowenstein, 1997). The decrease in

Table 2. Absolute counts of T-cell subsets $\ddagger$ in peripheral blood of very healthy subjects§ (Mean values and standard deviations)

\begin{tabular}{|c|c|c|c|c|c|c|}
\hline \multirow[t]{2}{*}{$n \ldots$} & \multicolumn{2}{|c|}{$\begin{array}{l}\text { Young adults } \\
46\end{array}$} & \multicolumn{2}{|c|}{$\begin{array}{l}\text { Young elderly (65-85 years of age) } \\
\qquad 30\end{array}$} & \multicolumn{2}{|c|}{$\begin{array}{l}\text { Old elderly (>90 years of age }) \\
16\end{array}$} \\
\hline & Mean & SD & Mean & $\mathrm{SD}$ & Mean & $\mathrm{SD}$ \\
\hline Age (years) & $29 \cdot 4$ & 3.5 & $77 \cdot 9$ & $5 \cdot 2$ & $94 \cdot 3$ & $3 \cdot 4$ \\
\hline Lymphocytes $\left(/ \mathrm{mm}^{3}\right)$ & 2210 & 470 & 1980 & 620 & $1830^{*}$ & 680 \\
\hline $\mathrm{CD} 2+\left(/ \mathrm{mm}^{3}\right)$ & 1980 & 310 & $1730^{\star *}$ & 410 & $1605^{\star *}$ & 470 \\
\hline $\mathrm{CD} 3+\left(/ \mathrm{mm}^{3}\right)$ & 1850 & 280 & $1510^{* * *}$ & 320 & $1360^{* *} \dagger$ & 380 \\
\hline $\mathrm{CD} 2+\mathrm{CD} 3\left(/ \mathrm{mm}^{3}\right)$ & 130 & 130 & $220^{*}$ & 210 & $240^{*}$ & 250 \\
\hline $\mathrm{CD} 57+\left(/ \mathrm{mm}^{3}\right)$ & 210 & 135 & $390^{\star * *}$ & 180 & $430^{\star * *}$ & 205 \\
\hline $\mathrm{CD} 4+\left(/ \mathrm{mm}^{3}\right)^{\prime}$ & 1245 & 1190 & $1115^{*}$ & 260 & $1084^{*}$ & 290 \\
\hline $\mathrm{CD} 8+\left(/ \mathrm{mm}^{3}\right)$ & 670 & 145 & $460^{* * *}$ & 190 & $405^{\star \star *}$ & 220 \\
\hline CD45RA $\left(/ \mathrm{mm}^{3}\right)$ & 1230 & 340 & $560^{* * *}$ & 180 & $380^{* * *} \dagger \dagger$ & 200 \\
\hline $\mathrm{CD} 45 \mathrm{RO}\left(/ \mathrm{mm}^{3}\right)$ & 760 & 235 & $1090^{* * *}$ & 420 & $1125^{\star * *}$ & 470 \\
\hline
\end{tabular}

CD45RA, memory T lymphocytes; CD45RO, naive T lymphocytes.

Mean values were significantly different from those for the young adults: ${ }^{\star} P<0.05,{ }^{* \star} P<0.01,{ }^{\star * \star} P<0.001$.

Mean values were significantly different from those for the young elderly: $\dagger P<0.05, \dagger \dagger P<0.01$.

‡ Quantified on freshly drawn blood, as previously described (Lesourd et al. 1994).

$\S$ Healthy young adults (25-34 years of age) and elderly of different ages were selected according to the SENIEUR protocol (Ligthart et al. 1984) and additional criteria (Lesourd et al. 1994; Lesourd \& Meaume, 1994). 
the CD8+ subset is mainly associated with a decrease in CD8+ cells expressing high levels of CD8, partly compensated by an increase in CD8+ cells expressing low levels of CD8. The increase in the latter type of CD8+ cells (Lesourd et al. 1994; Mazari \& Lesourd, 1998) suggests that they may be generated not in the thymus but elsewhere, perhaps in the liver as demonstrated in aged mice (Abo, 1992; Nakayama et al. 1994). We also found an increase in low-CD8 cells in aged mice (Barrat et al. 1997). Reports of a decreased CD4+ subset are consistently derived from studies of apparentlyhealthy elderly subjects, so may not be related to primary immune changes. In contrast, increased proportions of CD8+ cells have been reported in very healthy elderly subjects (Wick \& Grubeck-Lowenstein, 1997), leading to confusing results even in this carefully-selected population. In any case, the observed changes are minor $(<20 \%)$ and may not be sufficient to explain an immune deficiency state.

\section{T-cell functions}

Ageing is associated with impairment of T-cell functions, the most important being the decline in T-cell proliferation (Murasko et al. 1987; Nagel et al. 1988; Shearer, 1997) and the decrease in IL-2 synthesis (Rabinowich et al. 1985; Nagel et al. 1988; Shearer, 1997). Age-related decreased proliferation as well as decreased IL-2 secretion are, at least partly, related to the changes in T-cell subsets. Increases in memory T-cells may also be significant in the decreased lymphocyte proliferation observed, since memory cells are poor IL-2 secretors (Nagelkerken et al. 1991; Hobbs \& Ernst, 1997). In addition, immature CD2+CD3- cells, which increase with ageing, have a lower capacity to replicate (Alès-Martinez et al. 1988; Lesourd \& Meaume, 1994). Decreased lymphocyte reactivity is also at least partly associated with age-related increases in membrane viscosity (Huber et al. 1991), inducing signal transduction defects (Ca mobilization and/or protein phosphorylation) which increase with age (Ghosh \& Miller, 1995). This process leads to lower entry of the cells into the cell cycle, and to lower proto-oncogene expression (c-myc gene; Gamble et al. 1990), and inhibits cell progression (Perillo et al. 1993).

Nevertheless, contradictory results have been reported: lymphocyte proliferation was reported to be higher in the nonagenarians than in younger (75-90 years) aged individuals and this difference was related to different genetic background in survivors (Proust et al. 1982; Yong-Xing et al. 1997). We have recently reported (Mazari $\&$ Lesourd, 1998) that proliferation of lymphocytes from very-carefully-selected healthy elderly subjects without any micronutrient deficiency is comparable with that from similarly healthy young adults. It is then possible that the reported age-related decline in T-cell proliferation may be mainly, if not totally, due to selection bias (studied population not completely healthy), different genetic background and/or difference in nutritional status (cf. p. 690).

Approximately 8 years ago, Kubo \& Cinader (1990) reported that IL-2 does not decrease with age in some mouse strains, i.e. DBA1 and DBA2. A recent report has confirmed this finding in other strains (Engwerda et al. 1996). In human subjects it has been shown that serum IL-2 has the same relationship with health status in adult and young aged (60-70 years) individuals (Mysliwska et al. 1998), indicating that in vivo IL-2 secretion capacities are comparable. We recently reported (Mazari \& Lesourd, 1998) that in vitro IL-2 release from phytohaemagglutinintreated mononuclear cell cultures is comparable with lymphocytes from 25-34-year-old adults and those from 75-84-year-old very healthy elderly subjects having no micronutrient deficiency. In addition, we reported that in this very-carefully-selected healthy elderly population a minor micronutrient deficit such as low folate levels is associated with decreased IL-2 production and decreased lymphocyte proliferation (Mazari \& Lesourd, 1998). Once again it appears that changes in immune function in aged individuals may be more related to environmental factors such as health and/or nutritional status than to ageing per se.

Since the early 1990s immune ageing has also been described as including a change in T-helper (TH) $1: \mathrm{TH} 2$ cells, due to decreased TH1 function (mainly a decrease in IL-2 or interferon- $\gamma$ secretion) and increased TH2 function (IL-4 and IL-6 release; Kubo \& Cinader, 1990). We have shown that the decreased IL-2 secretion and, therefore, the decrease in TH1 function is not as obvious in the very healthy elderly, and that many factors, all related to health or nutritional status, may explain the frequently observed decrease in IL-2 (Mazari \& Lesourd, 1998). In addition, contradictory results have been reported for age-related interferon- $\gamma$ variations which have been found to remain constant or to decrease (Chen et al. 1987; Sindermann et al. 1993) with age. In fact interferon- $\gamma$ is also secreted by memory T-cells, a subset which increases with age (Sanders et al. 1998), and the apparently contradictory results may be related to different values for naive : memory $\mathrm{T}$ lymphocytes in the populations studied. The age-related decrease in the TH1 subset in the very healthy population needs to be confirmed in very carefully conducted studies, but is highly probable since the decreased $\mathrm{CD} 8+$ cytotoxic T-cell functions may be restored by exogenous IL-12, a TH1 cytokine (Mbawuike et al. 1997). In contrast, the more recently reported rise in IL-6 secretion by lymphocytes from aged individuals, a TH2 function, is probably an ageing phenomenon. IL-6 secretion is increased in aged individuals (Daynes et al. 1993; Erschler et al. 1993; James et al. 1997), even in the very-carefully-selected healthy elderly (Mazari \& Lesourd, 1998). It has been reported recently that this phenomenon starts in middle age (between age 36 and 59 years; Mysliwska et al. 1998), and is more pronounced in the very old (nonagenarians) than in the young old (Table 3). Thus, the age-related change in TH1 and TH2 function is an age-related immune change which is probably due to cumulative antigenic influence throughout the lifespan, since cumulative antigenic influence has been reported to be associated with a lower TH1: TH2 (Cakman et al. 1996). The decrease in TH1: TH2 may be of great importance in age-related immune changes, since TH1 mainly induces maturation and activation of the cytotoxic $\mathrm{T}$ lymphocytes which decrease with ageing (Bruley-Rosset \& Payelle, 1987; Mbawuike et al. 1997), while TH2 induces increased B lymphocyte immunoglobulin production which increases with ageing (Batory et al. 1984; Moulias et al. 1984). 
Table 3. Lymphocyte functions from peripheral phytohaemagglutinin (PHA)-stimulated T lymphocytes $\dagger$ from very healthy individuals (Mean values and standard deviations)

\begin{tabular}{|c|c|c|c|c|c|c|}
\hline \multirow[t]{2}{*}{$n \ldots$} & \multicolumn{2}{|c|}{$\begin{array}{l}\text { Young adults } \dagger \\
24\end{array}$} & \multicolumn{2}{|c|}{$\begin{array}{l}\text { Young elderly } † \\
27\end{array}$} & \multicolumn{2}{|c|}{$\begin{array}{l}\text { Old elderly† } \\
\qquad 17\end{array}$} \\
\hline & Mean & $\mathrm{SD}$ & Mean & SD & Mean & SD \\
\hline Age (years) & $28 \cdot 6$ & $3 \cdot 9$ & $79 \cdot 4^{* * *}$ & 4.9 & & \\
\hline Albumin $(\mathrm{g} / \mathrm{l})$ & 43.4 & 2.9 & 42.5 & $4 \cdot 2$ & 41.2 & 3.8 \\
\hline C-reactive protein $(\mathrm{mg} / \mathrm{l})$ & \multicolumn{2}{|c|}{$<6$} & \multicolumn{2}{|c|}{$<6$} & \multicolumn{2}{|c|}{$<6$} \\
\hline \multicolumn{7}{|l|}{ Lymphocyte proliferation } \\
\hline \multicolumn{7}{|l|}{ Purified PHA ( $1 \mu \mathrm{g} / 10^{6}$ cells $)$} \\
\hline$\left[{ }^{3} \mathrm{H}\right]$ Thymidine $\left(\mathrm{cpm} / 10^{3}\right.$ cells $)$ & 110 & 28 & 98 & 29 & 77 & 32 \\
\hline Percentage of CD25+ cells at $72 \mathrm{~h}$ & $66 \cdot 2$ & $7 \cdot 8$ & $59 \cdot 8$ & $7 \cdot 9$ & $42 \cdot 3^{\star *}$ & $9 \cdot 5$ \\
\hline \multicolumn{7}{|l|}{$\begin{array}{l}\text { In vitro cytokine release after } 22-24 \mathrm{~h} \\
\text { cultures }\end{array}$} \\
\hline IL-2 (ng/ml) & 1.62 & 0.27 & 1.53 & 0.34 & $1 \cdot 17$ & 0.45 \\
\hline IL-6 (ng/ml) & $1 \cdot 32$ & $0 \cdot 13$ & $1 \cdot 75^{*}$ & 0.23 & $1.96^{* *}$ & 0.34 \\
\hline
\end{tabular}

IL, interleukin; cpm, counts/min.

Mean values were significantly different from those of young adults: ${ }^{*} P<0.04,{ }^{* *} P<0.02,{ }^{* \star *} P<0.001$.

$\dagger$ Procedures for PHA-stimulated cultures, and quantification of lymphocyte proliferation and of supernatant fraction cytokine levels were performed as previously described (Lesourd et al. 1994; Mazari \& Lesourd, 1998)

¥ Young adults (25-34 years) and young elderly (75-84 years) were selected according to the SENIEUR protocol (Ligthart et al. 1984) plus additional criteria (Lesourd et al. 1994; Lesourd \& Mearne, 1994). Old elderly were recruited using the same criteria except the age class did not fit the SENIEUR criteria.

\section{Humoral immunity}

Humoral immune responses are less severely affected by the ageing process than cell-mediated immunity (Lesourd, 1990a). Blood levels of immunoglobulins $\mathrm{G}$ and A are increased in the very old, indicating an effective $\mathrm{TH} 2$ response (Batory et al. 1984; Moulias et al. 1984). Primary antibody responses are decreased while booster responses are preserved (Moulias et al. 1985), indicating that changes in antibody production are mainly due to the acquisition of new TH cells (Miller, 1996). The decreased antibody response has also been shown to be associated with increased anti-idiotype antibodies (Arreaza et al. 1993), which lead to production of antibodies with lower antigenic affinity (Muller et al. 1986). The lower affinity of the antibody produced has also been related to changes in B-cell subsets: CD5+ lymphocytes which secrete autoantibodies increase with age, while CD5- lymphocytes which produce antibodies against foreign antigens decrease (Weksler, 1995). Thus, even though antibody production is mildly reduced in the aged individuals, the specificity and the affinity of the secreted antibody is reduced, leading to lessadapted antibody responses.

\section{Monocyte-macrophage functions}

Macrophage functions seem to be preserved or even enhanced with ageing. Antigen processing and presentation are comparable in young and old mice (Doria, 1988). IL-1 production is sustained in old mice (Goldberg et al. 1991) and human subjects (Nafziger et al. 1993), while IL-6 production is increased (Table 4). This finding represents another disequilibrium in the immune response of aged persons; preserved functions of accessory cells and decreased functions of T lymphocytes. This process may be of great consequence for the adaptive immune response to antigenic challenge. Indeed, as T-cell proliferation is decreased, T lymphocytes need to be stimulated more to react in a suitable manner to antigenic challenge (Lesourd \& Mazari, 1997). The greater secretion of macrophage cytokines in response to antigenic challenge leads to greater or longer-lasting body metabolic changes in old individuals (Cederholm et al. 1997), since monokines play a central role in controlling body metabolism (Klasing, 1988; Lesourd, 1992). Monokines induce (directly or indirectly via hormonal secretions) muscle protein breakdown, which is particularly damaging in old individuals since ageing per se induces increased muscle protein catabolism (Fereday et al. 1997), and reduced protein synthesis (Welle et al. 1993; Yarasheski et al. 1993). Thus, any antigenic challenge or any disease will induce higher muscle protein breakdown in aged subjects than in adults, and the muscle destroyed is not fully rebuilt after recovery. Any disease leads to some muscle loss (protein body reserve). When disease follows disease, protein body reserves decrease, which will push the elderly into progressive and gradually increasing proteinenergy malnutrition (PEM), and, therefore, to progressive and gradually reduced immune responses. As decreased immune responses increase the risk of infection, the diseaseinduced increase in muscle loss makes occurrence of new diseases more likely, which worsens muscle protein loss, worsening PEM and inducing lower immune responses. The macrophage-T lymphocyte imbalance is therefore part of the ageing process which precipitates aged individuals towards frailty.

In addition, it has been shown recently that the monocyte production of prostaglandin $\mathrm{E}_{2}$, a suppressive factor for $\mathrm{T}$ lymphocytes, is enhanced with ageing and partly contributes to the age-related decrease in T-cell functions (Hayek et al. 1997). As lymphocytes of aged individuals are particularly sensitive to prostaglandin $\mathrm{E}_{2}$ production (Goodwin, 1982), the increased metabolic production of prostaglandin $E_{2}$ from macrophages of aged individuals further promotes macrophage-T lymphocyte dysregulation. This process may 
Table 4. Monocyte cytokine releases in lipopolysaccharide-stimulated culturesł from very healthy individuals (Mean values and standard deviations)

\begin{tabular}{|c|c|c|c|c|c|c|c|c|}
\hline \multirow[t]{2}{*}{$n \ldots$} & \multicolumn{2}{|c|}{$\begin{array}{l}\text { Young adults§ } \\
\qquad 36\end{array}$} & \multicolumn{2}{|c|}{$\begin{array}{c}\text { Young elderly§ } \\
27\end{array}$} & \multicolumn{2}{|c|}{$\begin{array}{l}\text { Old elderly§ } \\
16\end{array}$} & \multicolumn{2}{|c|}{$\begin{array}{c}\text { PEM elderly§ } \\
45\end{array}$} \\
\hline & Mean & SD & Mean & SD & Mean & SD & Mean & SD \\
\hline Age (years) & $29 \cdot 3$ & 3.6 & $79 \cdot 4^{\star \star *}$ & 4.9 & \multicolumn{2}{|c|}{$>90^{* \star \star}$} & $85 \cdot 3^{\star * *}$ & $7 \cdot 3$ \\
\hline Albumin $(\mathrm{g} / \mathrm{l})$ & $43 \cdot 7$ & $2 \cdot 6$ & 42.5 & $4 \cdot 2$ & $42 \cdot 1$ & 3.8 & $26 \cdot 1^{* * *}+\dagger \dagger$ & $4 \cdot 4$ \\
\hline C-reactive protein $(\mathrm{mg} / \mathrm{l})$ & \multicolumn{2}{|c|}{$<6$} & \multicolumn{2}{|c|}{$<6$} & \multicolumn{2}{|c|}{$<6$} & $21 \cdot 7+\dagger$ & $6 \cdot 3$ \\
\hline \multicolumn{9}{|l|}{ Interleukin $1(\mathrm{ng} / \mathrm{ml})$} \\
\hline Spontaneous & \multicolumn{2}{|c|}{ ND } & 0.3 & 1.5 & 0.3 & 1.3 & $2 \cdot 6$ & $2 \cdot 1$ \\
\hline Stimulated & $2 \cdot 7$ & $2 \cdot 1$ & 2.5 & 2.5 & $2 \cdot 6$ & $3 \cdot 1$ & $1 \cdot 0$ & 0.8 \\
\hline \multicolumn{9}{|l|}{ Interleukin $6(\mathrm{ng} / \mathrm{ml})$} \\
\hline Spontaneous & \multicolumn{2}{|c|}{ ND } & \multicolumn{2}{|c|}{ ND } & \multicolumn{2}{|c|}{ ND } & 0.24 & 0.11 \\
\hline Stimulated & $1 \cdot 22$ & 0.31 & 1.45 & 0.27 & 1.56 & 0.39 & $0 \cdot 78 \dagger \dagger$ & 0.37 \\
\hline
\end{tabular}

PEM, protein-energy malnutrition; ND, not detected.

Mean values were significantly different from those for young adults: ${ }^{* \star} P<0.001$.

Mean values for PEM elderly were significantly different from those for the young elderly: $++P<0.01,+t+P<0.001$.

¥ Procedures for lipopolysaccharide-stimulated cultures and quantification of supernatant fraction cytokine levels were as previously described (Lesourd et al. 1994).

$\S$ Healthy young adults (25-34 years) and young elderly (75-84 years) were selected according to the SENIEUR protocol (Ligthart et al. 1984) and additional criteria (Lesourd et al. 1994; Lesourd \& Meaurne, 1994).

be the explanation for the observed moderate response when dendritic cells from elderly individuals are stimulated with influenza virus (Wick \& Grubeck-Lowenstein, 1997).

\section{Secondary alterations in immune responses in the elderly: influence of nutritional factors}

Numerous studies have investigated immune responses in apparently-healthy elderly subjects and diseased elderly subjects. We would like to briefly review those data, particularly those concerning the influence of nutritional factors in healthy or apparently-healthy elderly subjects in whom immune responses are influenced by ageing and by environmental factors, especially diet.

\section{Apparently-healthy elderly}

We have focused our research on immune responses in different groups of aged subjects characterized by their health status. In addition, we checked all elderly subjects in apparently good health for nutritional status by simultaneous quantification not only of weight and BMI, but also several nutritional biological variables, including serum proteins (albumin and transthyretin) for protein status, serum $\mathrm{Zn}$ and $\mathrm{Se}$ for trace element status, and serum vitamins $\mathrm{A}, \mathrm{C}, \mathrm{E}, \mathrm{B}_{6}$ and $\mathrm{B}_{12}$ and folate for vitamin status. All subjects were classified for each nutritional variable as either normal according to our laboratory data for healthy adults, or as nutritionally deficient if any of the tested variables was under the cut-off point using the criteria of the EURONUT/Seneca study (Haller et al. 1996). According to our classification, we have been able to select very healthy elderly (SENIEUR protocol plus additional criteria; see Table 1) for whom all nutritional variables were in the normal range, and apparently-healthy elderly (SENIEUR protocol plus additional criteria; see Table 1) for whom only one nutritional variable was not within the normal range, i.e. albumin, $\mathrm{Zn}$ or folate levels. We were then able to measure the reciprocal influences of ageing per se (in the very healthy elderly group) and the influence of nutritional factors on immune responses in apparently-healthy elderly subjects.

Decreased nutritional status (assessed as decreased serum albumin, although in the normal range (35-40 g/l)), is associated with important changes in T-cell subsets and in T-cell functions. In the groups of very healthy elderly lower levels of serum albumin are linked with lower levels of CD3+ mature T-lymphocytes, lower levels of CD8+, higher levels of CD2+CD4-CD8- double negatives and of CD2+CD3- immature T lymphocytes, and higher levels of CD57+ NK cells (Lesourd et al. 1994; Lesourd \& Meaume, 1994). In addition, CD45RO memory cells are decreased, while CD45RA naive cells are increased (Mazari \& Lesourd, 1998). The changes in T lymphocyte subsets are correlated with the decrease in albumin levels, indicating an influence of low nutritional status on those changes (Lesourd et al. 1994; Lesourd \& Meaume, 1994). In addition, all elderly subjects with low albumin levels expressed decreased levels of CD4+ subset, a change we had not observed in the elderly with high serum albumin levels (> $40 \mathrm{~g} / \mathrm{l}$; Mazari \& Lesourd, 1998). Immune functions, as measured by lymphocyte proliferation and in vitro IL-2 release from phytohaemagglutinin-stimulated lymphocyte cultures, are also lowered when compared with values for very healthy elderly subjects with higher serum albumin levels. In addition, IL- 6 release from phytohaemagglutinin-stimulated cultures is also decreased and comparable with that of cultures performed on the same day from lymphocytes of healthy adult controls (Mazari \& Lesourd, 1998). Thus, it appears that small changes in protein nutritional status, reflecting a small nutritional deficit, is associated in aged individuals with an increase in the age-related immune changes and with a general decrease in immune functions. In addition, we have shown that low folate levels (either serum or erythrocyte folates) are associated with decreased lymphocyte proliferation when measured by the kinetics of CD25 appearance in phytohaemagglutinin-stimulated lymphocyte cultures, indicating 
that decreased lymphocyte proliferation in elderly subjects may be due to minor short-term changes in nutritional status. The fact that decreased folate levels are not associated with decreased lymphocyte proliferation in healthy young adults (Mazari \& Lesourd, 1998) indicates that immune responses of old subjects are more sensitive to nutritional influences than those of young adults. Thus, it is logical to ask what role nutrition plays in the reported data on immune ageing.

We also evaluated the influence of nutrition on monocyte functions in similar groups of elderly subjects (Lesourd et al. 1998; B Lesourd and L Mazari, unpublished results). Very healthy elderly subjects with lower BMI release lower levels of IL-1 and IL-6 from lipopolysaccharide-stimulated monocyte cultures than similar elderly subjects with higher BMI (Table 4). In addition, these subjects have increased serum C-reactive protein and $\alpha-1$-glycoprotein acid levels, indicating a probable in vivo activation of monocytes, since acute-phase protein synthesis is boosted by monocyte cytokines even though we have been unable to detect any increase in serum cytokines. The decreased in vitro cytokine release may be due to limited capacity of monocyte secretions in aged individuals. In fact, we have reported that during acute pulmonary infections the rise in IL-1 from lipopolysaccharide-stimulated cultures is lower in aged individuals compared with young adult counterparts (Nafziger et al. 1993). Is the influence of in vivo stimulation of the immune system, even at low levels, playing a role on in vitro quantification of the immune system in the apparently-healthy elderly? Is such an influence part of the observed immune ageing in less carefully selected aged individuals? Further studies investigating the health status of aged individuals in a careful and extensive way will permit us to answer these questions.

Lipids probably play a role in the age-related changes in immune responses. During $\mathrm{T}$ lymphocyte proliferation induced by mitogens the membrane lipid composition changes, and this change is altered during lymphoblastoid transformation in the elderly (Stulnig et al. 1995). In addition, the change in membrane lipid composition observed in aged individuals is correlated with a decreased mitogenic response (Wick et al. 1991). This response was reported to be due to higher plasma membrane viscosity (Traill et al. 1985) in peripheral lymphocytes of healthy elderly subjects. Indeed, membrane viscosity is highly negatively correlated with mitogenic responses of T lymphocytes (Huber et al. 1991; Wick \& Grubeck-Lowenstein, 1997). Changes in membrane viscosity are more pronounced in lymphocytes from unhealthy elderly subjects than healthy elderly subjects, the former also expressing lower proliferation ability (Wick \& Grubeck-Lowenstein, 1997). Thus, it was postulated that part of the altered lymphocyte proliferation is due to increased membrane viscosity, even in the healthy elderly. In addition, membrane viscosity may be reduced by in vivo lipid-lowering drug treatment or by changes in dietary lipid, which reduce the free cholesterol to phospholipid and the $n-3: n-6$ value respectively in the membrane; such treatments induce higher mitogenic activity (Wick et al. 1991). The influence of dietary lipid on the immune responses of healthy elderly subjects in comparison with young adults needs to be further investigated.
Several reports have addressed the question of the influence of micronutrient deficits in apparently-healthy self-sufficient home-living elderly subjects. Most of these studies have tried to determine the influence of nutritional supplementation on immune responses of aged individuals using supplementation with either one, a few, or many micronutrients. It was first shown that vitamin $\mathrm{B}_{6}$ supplementation induces higher lymphocyte proliferation in aged subjects in relation to increased responses in vitamin $\mathrm{B}_{6}$-deficient individuals (Talbott et al. 1987). Later, the influence of vitamin $\mathrm{B}_{6}$ on immune responses of aged individuals was established by a depletion-repletion study in healthy elderly subjects (Meydani et al. 1991). The role of vitamin $\mathrm{B}_{6}$ deficiency on immune responses of apparentlyhealthy elderly subjects (SENIEUR protocol) may be strongly suspected since vitamin $\mathrm{B}_{6}$ deficiency is common in home-living self-sufficient elderly subjects. Indeed, up to $18 \%$ of these subjects were shown to have insufficient intakes in the EURONUT/Seneca study (Amorin-Cruz et al. 1996; Lesourd et al. 1998) and up to $7 \%$ to have low serum pyridoxal 5'-phosphate values (Haller et al. 1996). Onethird of low-income elderly individuals have plasma pyridoxal 5'-phosphate levels below $30 \mathrm{nmol} / \mathrm{l}$ (Garry et al. 1982). In addition, $\mathrm{Zn}$ deficiency is extremely frequent in the elderly (Prasad et al. 1993). Both Zn (Keen \& Gershwin, 1990; Cunningham-Rundles et al. 1991) and vitamin $B_{6}$ (Chandra \& Sudhakaran, 1990; Rall \& Meydani, 1993) deficiencies are associated with immunodeficiencies which closely resemble the age-related immune changes. Thus, it is more than likely that some of the carefully-selected elderly subjects (SENIEUR protocol) had a micronutrient deficit which may be of importance for their immune responses. The importance of such nutritional influences on the immune ageing reported remains to be determined. In addition, it has been shown in apparently-healthy elderly subjects that multi-micronutrient supplementation at one to three times RDA levels may induce greater immune responses (Bogden et al. 1990, 1994; Penn et al. 1991; Chandra, 1992a; Boukaïba et al. 1993), probably due to correction of minor micronutrient deficiencies (Bogden et al. 1990; Chandra, 1992a). The influence of minor micronutrient deficiencies on immune responses of aged individuals is obvious even in the healthiest individuals. Thus, studies investigating immune ageing must be performed in individuals who have been assessed for micronutrient status. Assessment must be performed simultaneously with immune measurements, since some micronutrient deficits (such as low folate levels) may occur within a few days.

Furthermore, very high levels of vitamin E supplementation (200-800 mg N- $\alpha$-tocopheryl acerate/d) also lead to increased immune responses (Meydani et al. 1990, 1997) even though vitamin E deficiency is uncommon in the aged population (less than $1 \%$ in the EURONUT/Seneca study (Amorin-Cruz et al. 1996; Lesourd et al. 1998) Vitamin E supplementation was associated with decreased free radical and decreased prostaglandin $\mathrm{E}_{2}$ (Cannon et al. 1991; Meydani et al. 1995) production by monocytes; both factors which are increased in aged individuals (Lang et al. 1992; Harman, 1995; Hayek et al. 1997). Free radical production is enhanced during cell activation. Thus, any acute-phase 
response induces increased free radical production. We (Mazari \& Lesourd, 1998) have shown that very healthy elderly (SENIEUR protocol plus additional criteria) with lower BMI have increased C-reactive protein and $\alpha-1$ glycoprotein acid levels, and as a consequence they would have increased free radical production which may contribute towards the lower immune responses observed in this group of elderly subjects. Thus, immune ageing per se must be studied in aged individuals without any detectable acutephase responses, which has not yet been done.

\section{Undernourished elderly}

PEM exerts a strong influence on immune responses in aged individuals (Chandra, 1989, 1992; Lesourd et al 1990a,b). In this group, whatever the assay used for quantification of cell-mediated immunity, immune responses are always decreased compared with healthy or even apparentlyhealthy elderly subjects (for review, see Lesourd et al. 1998). This finding has been confirmed for the T-cell subsets which change with ageing: decreased CD3+ and CD8+ subsets, increased CD2+CD3-, double negative CD2+CD4-CD8- subset and CD57+ NK cells. In addition, CD4+ numbers are decreased in undernourished elderly subjects. T lymphocyte functions (lymphocyte proliferation, cytokine release from mitogen-stimulated cultures, cytotoxic capacities and delayed type hypersensitivity etc.) are lowered. The decrease in immune functions is highly correlated with the intensity of the nutritional deficit (Chandra, 1989; Lesourd, 1990b; Lesourd et al. 1992), leading to profound immunodeficiency in elderly patients with severe PEM. It was shown that ambulatory elderly individuals with serum albumin levels lower than $30 \mathrm{~g} / \mathrm{l}$ have lymphopaenia and peripheral blood CD4+ counts lower than $400 / \mathrm{mm}^{3}$; a level associated with acute acquired immune deficiency syndrome in human immunodeficiency virus pathology (Lesourd, 1990a, 1995). PEM is also associated with greatly decreased vaccine antibody responses in the elderly population (Lesourd, 1990b, 1995; Chandra, 1994). PEM also has a major effect on innate immunity in the elderly (Lipschitz \& Udupa, 1986; Rudd \& Banerjee, 1989; Lesourd, 1999). It has been shown that PEM and ageing exert cumulative influences on immune responses in the elderly (Lipschitz \& Udupa, 1986). In addition, immune changes observed in undernourished elderly subjects may be reversed by refeeding therapy (Chandra, 1992a; Lesourd, 1995, 1999; Lesourd \& Mazari, 1997).

Not only does PEM exert a profound effect on the immune responses of aged individuals, but micronutrient deficiencies, mainly $\mathrm{Zn}$ and vitamin $\mathrm{B}_{6}$ deficiencies (for review, see Lesourd et al. 1998), have the same effects. Nutritive therapy using vitamin $\mathrm{B}_{6}$ (Talbott et al. 1987; Rall \& Meydani, 1993) or Zn (Boukaïba et al. 1993), or a combination of several micronutrients (Penn et al. 1991; Fortes et al. 1993; Galan et al., 1997; ) induces increased immune responses in aged patients, but may also have detrimental effects (high doses of $\mathrm{Zn}$ (Bogden et al. 1990) or RDA dose of vitamin A (Fortes et al. 1993)).

\section{Conclusion}

Restriction of food intake has been shown to increase lifespan and to slow down immune ageing in rodents. Conversely, there is strong evidence that undernutrition induces immunodeficiency irrespective of the nutrient affected. The present review provides evidence that human immune ageing is strongly influenced by nutritional factors, mainly low nutritional status in either macro- or micronutrients. Indeed, very-carefully-selected healthy elderly subjects have cell-mediated immune variables, i.e. peripheral blood $\mathrm{T}$ lymphocyte susbsets and/or $\mathrm{T}$ lymphocyte functions that resemble those of young adult controls. In addition, elderly subjects with protein or micronutrient deficiency exhibit cell-mediated immune responses that fit almost exactly those generally described as agerelated changes in immune responses. Furthermore, micronutrient supplementation, at the RDA level but also at higher doses, enhance immune responses of aged individuals almost to levels comparable with those of healthy adults. There is strong evidence that nutritional status greatly influences immune responses of aged individuals, and that this is an important part of what is known as immune ageing. Carefully designed studies need to be conducted in order to separate the respective roles of primary immune deficiency (immune ageing per se) and nutritionally-induced secondary immune deficiency in aged subjects. In addition, the levels of micronutients necessary to slow down the immune ageing process remain to be investigated.

\section{References}

Abo T (1992) Extrathymic differentiation of T lymphocytes and its biological function. Biology in Medical Research 13, 1-39.

Alès-Martinez JE, Alvarez-Mon M, Merino F, Bonilla F, Martinez C, Durantez A \& De La Hera A (1988) Decreased TcR-CD3-T cell numbers in healthy aged humans. Evidence that $\mathrm{T}$ cell defects are masked by a reciprocal increase of TcR-CD3-CD2+ natural killer cells. European Journal of Immunology 18, 1827-1830.

Amorin-Cruz JA, Moreiras O \& Brzozowska A (1996) Longitudinal changes in the intakes of vitamins and minerals of elderly Europeans. European Journal of Clinical Nutrition 50, Suppl. 2, S77-S85.

Arreaza EE, Gibbons JJ, Sisking GW \& Weksler ME (1993) Lower antibody response to tetanus toxoid associated with higher auto-anti-idiotype antibody in old compared with young humans. Clinical and Experimental Immunology 92, 169-176.

Barrat F, Lesourd BM, Louise A, Boulouis HJ, Vincent-Naulleau S, Thibault D, Neway T, Sanaa M \& Pilet Ch. (1997) Surface antigens expression in spleen cells of C57 B1/6 mice during aging: influence of sex and breeding. Clinical and Experimental Immunology 107, 593-600.

Batory G, Janeso A, Puskas E, Redei A \& Lengyei E (1984) Antibody and immunoglobulin levels in aged humans. Archives of Gerontology and Geriatrics 3, 175-188.

Ben-Yehuda A, Szabo P \& Weksler ME (1994) Age associated changes in the B-cell: effect of age on RAG-1 gene expression in murine bone marrow. Immunology Letters 40, 287-290.

Bogden JD, Oleske JM, Lavenhar MA, Munves EM, Kemp FW, Bruening KS, Holding KJ, Denny TN, Guarino MA \& Holland BK (1990) Effects of one year of supplementation with zinc and 
other micronutrients on cellular immunity in the elderly. Journal of the American College of Nutrition 9, 214-225.

Bogden JD, Bendich A, Kemp FW, Bruening KS, Shurrick JH, Denny T, Baker H \& Louria DB (1994) Daily micronutrient supplements enhanced delayed-hypersensitivity skin test responses in older people. American Journal of Clinical Nutrition 60, 437-447.

Boukaïba N, Flament C, Acher S, Chappuis Ph, Pian A, Fusselier M, Dardenne M \& Lemonnier D (1993) A physiological amount of zinc supplementation: effects on nutritional, lipid, and thymic status in an elderly population. American Journal of Clinical Nutrition 57, 566-572.

Bruley-Roseet M \& Payelle B (1987) Deficient tumor specific immunity in old mice: in vivo mediation by suppressor cells, and correction of the defect interleukin 2 by supplementation in vitro but not in vivo. Journal of Immunology 17, 307-312.

Cakman I, Rohwer J, Schûtz RM, Kirchner H \& Rink L (1996) Dysregulation betwen TH1 and TH2 cell sub-populations in the elderly. Mechanisms of Ageing and Development 87, 197-209.

Cannon JG, Meydani SN, Fielding RA, Meydani M, Fiatarone MA, Farhangmehr M, Orencole SF, Blumberg JB \& Ewans WJ (1991) The acute phase response in exercise. II. Associations between vitamin E, cytokines and muscle proteolysis. American Journal of Physiology 260, R1235-R1240.

Cederholm T, Wretling B, Hellstrom K, Andersson B, Engstrom L, Brismark K, Scheynius A, Faslid J \& Palmblad J (1997) Enhanced generation of interleukins $1 \beta$ and 6 may contribute to the cachexia of chronic disease. American Journal of Clinical Nutrition 65, 876-882.

Chandra RK (1989) Nutrition, regulation of immunity and risk of infection on old age. Immunology 67, 141-147.

Chandra RK (1992a) Effect of vitamin and trace-element supplementation on immune responses and infection in elderly subjects. Lancet 340, 1124-1127.

Chandra RK (editor) (1992b) Nutrition and immunobiology: experience of an old traveller and recent observations. In Nutrition and Immunology, pp. 9-43. St John's, Nfld.: ARTS Biomedical.

Chandra RK (1994) Nutritional regulation of immune function at the extremes of life: in infants and in the elderly. In Malnutrition Determinants and Consequences, pp. 245-251 [P White, editor]. New York: Alan R Liss.

Chandra RK \& Sudhakaran L (1990) Regulation of immune responses by vitamin $\mathrm{B}_{6}$. Annals of New York Academy of Sciences 585, 404-423.

Chen WF, Liu SL, Gao XM \& Pang XI (1987) The capacity of lymphokine production by peripheral blood lymphocytes from aged humans. Immunology Investigation 15, 575-583.

Cossarizza A, Ortolani C, Paganelli R, Monti D, Barbieri D, Sansoni P, Fagiolo U, Forti E, Londei M \& Franceschi C (1992) Age-related imbalance of virgin (CD45RA+) and memory (CD45RO+) cells between CD4+ and CD8+ T lymphocytes in humans: study from newborns to centenarians. Journal of Immunology Research 4, 117-126.

Cunningham-Rundles S, Bockam RS, Lin A, Giardana PV, Hilgartner MW, Caldwell-Brown D \& Carter DM (1991) Physiological and pharmacological effects of zinc on immune response. Annals of the New York Academy of Sciences 590, 113-122.

Daynes RA, Areanéo BA, Ershler WB, Maloney C, Li GZ \& Ryu SY (1993) Altered regulation of IL-6 production with normal aging. Journal of Immunology 150, 5219-5230.

Doria G. (1988) Immunoregulation in aging. International Journal of Medicine 4, 83-85.
Engwerda CR, Fox BS \& Handwerger BS (1996) Cytokine production by $\mathrm{T}$ lymphocytes from young and old mice. Journal of Immunology 156, 3621-3630.

Ershler WB, Sun WH, Binkley N, Gravenstein S, Volk MJ, Kamoske G, Kloop RG, Roecker EB, Daynes RA \& Weindruch $R$ (1993) Interleukin-6 and aging: blood levels and mononuclear cell production increase with advancing age and in vitro production modifiable by dietary restriction. Lymphokine and Cytokine Research 12, 225-230.

Fereday A, Gibson NR, Cox M, Pacy PJ \& Millward DJ (1997) Protein requirements and ageing: metabolic demand and efficiency of utilization. British Journal of Nutrition 77, $685-702$.

Fernandes G, Venkatramen JT, Turturro A, Attwood VG \& Hart RW (1991) Effect of food restriction on lifespan and immune functions in long-lived Fischer-344 $\times$ Brown Norway F1 rats. Journal of Clinical Immunology 17, 85-95.

Fortes C, Forastiere F, Agabiti N, Fano V, Pacifici R, Virgili F, Piras G, Guidi L, Bartonoli C, Tricerri A, Ziccaro P, Ebrahim S \& Perucci CA (1993) The effects of zinc and vitamin A supplementation on immune response in an older population. Journal of the American Geriatrics Society 46, 19-26.

Galan P, Preziosi P, Monget AL, Richard MJ, Arnaud J, Lesourd B, Girodon F, Munoz Alferez M-J, Bourgeois C, Keller H, Favier A, Hercberg S \& the Geriatric Network MIN.VIT.AOX (1997) Effects of trace elements and/or vitamin supplementation on vitamin and mineral status, free radical metabolism and immunological markers in elderly long-term hospitalized subjects. International Journal of Vitamin and Nutrition Research 67, 450-460.

Gamble DA, Schwab R, Weksler ME \& Szabo P (1990) Decreased steady state c-myc mRNA in activated T cell cultures from old humans is caused by a smaller proportion of $\mathrm{T}$ cells that transcribe the c-myc gene. Journal of Immunology 114, 3569-3573.

Garry PJ, Goodwin JS, Hunt WC, Hooper ER \& Leonard AG (1982) Nutritional status in a healthy elderly population: dietary and supplementation intakes American Journal of Clinical Nutrition 36, 319-331.

Ghosh J \& Miller RA (1995) Rapid tyrosine phosphorylation of Grb2 and She in T cells exposed to anti-CD3, anti-CD4, antiCD45 stimuli: differential effects of ageing Mechanisms of Ageing and Development 80, 171-187.

Goldberg TH, Baker DG \& Shumacher HR (1991) Interleukin-1 and the immunology of aging and disease. Aging, Immunology and Infectious Diseases 3, 81-86.

Goodwin JS (1992) Changes in lymphocyte sensitivity to prostaglandin $\mathrm{E}_{2}$, histamine, hydrocortosone, and $\mathrm{X}$ irradiation with age: studies in a healthy elderly population. Clinical and Experimental Immunology and Immunopathology 25, 243-251.

Goto M \& Nishioka K (1989) Age- and sex-related changes of the lymphocyte subsets in healthy individuals: an analysis by two-dimensional flow cytometry. Journal of Gerontology 5, 242-253.

Haller J, Weggemans RM, Lammi-Keefe CJ \& Ferry M (1996) Changes in the vitamin status of elderly Europeans: plasma vitamins A, E, B-6, B-12, folic acid and carotenoids. European Journal of Clinical Nutrition 50, Suppl. 2, S32-S46.

Harman D (1995) Role of antioxidant nutrients in aging: overview. Age 18, 51-62.

Hayek GM, Mura C, Wu D, Beharka AA, Han SN, Paulson E, Hwang D \& Meydani SN (1997) Enhanced expression of inducible cyclooxygenase with age in murine macrophages. Journal of Immunology 159, 2445-2451. 
Hirokawa K., Utsuyama M., Kasai M, Kurishima C, Ishijima S \& Zeng YX (1994) Understanding the mechanisms of the age changes of thymic function to promote $\mathrm{T}$ cell differentiation. Immunology Letters 40, 269-277.

Hobbs MV \& Ernst DN (1997) T cell differentiation and cytokine expression in late life. Developmental and Comparative Immunology 21, 464-470.

Huber LA, Xu QB, Jürgens G, Böck G, Buther E, Gey KF, Schronitzer D, Traill KN \& Wick G (1991) Correlation of lymphocyte lipid composition membrane microviscosity and mitogen response in the aged. European Journal of Immunology 21, 2761-2765.

Huppert FA, Solomou W, O'Connor S, Morgan K, Sussams P \& Brayne C (1998) Aging and lymphocyte subpopulations: wholeblood analysis of immune markers in a large population sample of healthy elderly individuals. Experimental Immunology 33, 593-600.

James K, Premchand N, Skibinska A, Skibinski G, Nicol M \& Mason JI (1997) IL-6, DHEA and the ageing process. Mechanisms of Ageing and Development 93, 15-24.

Keen CL \& Gershwin ME (1990) Zinc deficiency and immune function. Annual Review of Nutrition 10, 415-431.

Klasing KC (1988) Nutritional aspects of leukocyte cytokines: critical review. Journal of Nutrition 11, 1436-1446.

Krishnaraj R (1997) Senescence and cytokines modulate the NK expression. Mechanisms of Ageing and Development 96, 89-116.

Kubo M \& Cinader B (1990) Polymorphism of age-related changes in interleukin (IL) production: differential changes of $\mathrm{T}$ helper subpopulation, synthesizing IL-2, IL-3, and IL-4. European Journal of Immunology 24, 133-136.

Lang GA, Naryshkin S, Schneider DL, Mills BJ \& Lindeman RD (1992) Low blood glutathionine levels in healthy aging adults. Journal of Laboratory and Clinical Medicine 120, 720-725.

Lesourd B (1990a) Le vieillissement immunologique: influence de la dénutrition (Immune ageing: influence of nutrition). Annales de Biologie Clinique 48, 309-318.

Lesourd B (1990b) La dénutrition protéique: principale cause de déficit immunitaire chez le sujet âgé (Protein malnutrition: the main cause of immunodeficiency in the elderly). Age and Nutrition 3, 132-138.

Lesourd B, (1992) Conséquences nutritionnelles des cytokines: facteur de gravité des hypercatabolismes chez le sujet âgé (Nutritional consequences of cytokine secretion: a prognosis factor of hypercatabolism in elderly). Age and Nutrition 3, 100-109.

Lesourd BM (1995) Protein undernutrition as the major cause of decreased immune function in the elderly: clinical and functional implications. Nutrition Reviews 53, S86-S94.

Lesourd B (1999) Immune response during disease and recovery in the elderly. Proceedings of the Nutrition Society 58, 85-98.

Lesourd B, Laisney C, Salvatore R, Meaume S \& Moulias R (1994) Decreased maturation of $\mathrm{T}$ cell population factors on the appearance of double negative CD4-, CD8-, CD2+ cells. Archives of Gerontology and Geriatrics 4 Suppl., 139-154.

Lesourd BM \& Mazari L (1997) Immune responses during recovery from protein-energy malnutrition. Clinical Nutrition 16, Suppl. 1, 37-46.

Lesourd B, Mazari L \& Ferry M (1998) The role of nutrition in immunity in the aged. Nutrition Reviews 56, S113-S125.

Lesourd B \& Meaume S (1994) Cell-mediated immunity changes in aging: relative importance of cell subpopulation switches and of nutritional factors. Immunology Letters 40, 235-242.

Lesourd BM, Moulias R, Favre-Berrone M \& Rapin CH (1992) Nutritional influences on immune responses in elderly. In Nutrition and Immunology, pp. 211-223 [RK Chandra, editor]. St John's, NPld: ARTS Biomedical.
Ligthart GJ, Corberand JX, Fournier C, Galanaud P, Hijmans W, Kennes B, Muller-Hermelink HK \& Steinmann GG (1984) Admission criteria for immunogerontological studies in man: the Senieur protocol. Mechanisms of Ageing and Development 28, 47-55.

Ligthart GJ, Van Vlokhoven PC, Schuit HRE \& Hijmans W (1986) The expanded null cell compartment in ageing: increase in the number of natural killer cells and changes in T-cell and NK-cells subset in human blood. Immunology 59, 353-357.

Lipschitz DA \& Udupa KB (1986) Influence of ageing and protein deficiency on neutrophil function. Journal of Gerontology 41, 281-288.

Makinodan T \& Kay MMB (1980) Age influence on the immune system. Advances in Immunology 29, 287-330.

Mazari L \& Lesourd B (1998) Nutritional influences on immune response in healthy aged persons. Mechanisms of Ageing and Development 104, 25-40.

Mbawuike IN, Acuna CL, Walz KC, Atmar RL, Greenberg SB \& Couch RB (1997) Cytokines and impaired CD8+ CTL activity among elderly persons and the enhancing effect of IL-12. Mechanisms of Ageing and Development 94, 25-39.

Meydani SN, Barklund MP, Lui S, Meydani M \& Miller RA (1990) Vitamin E supplementation enhances cell-mediated immunity in healthy elderly. American Journal of Clinical Nutrition 52, $557-563$

Meydani SN, Meydani M, Blumberg JB, Lekal S, Siber G, Loszewski R, Thompson C, Pedrosa C, Diamond RD \& Stollar BD (1997) Vitamin E supplementation and in vivo immune responses in healthy elderly subject. Journal of the American Medical Association 277, 1380-1386.

Meydani SN, Ribaya-Mercado JD, Russell RB, Sahyoun N, Morrow FD \& Gershoff SN (1991) Vitamin B-6 deficiency impairs interleukin 2 production and lymphocyte proliferation in elderly adults American Journal of Clinical Nutrition 53, $1275-1280$.

Meydani SN, Wu D, Santos MS \& Hayek MG (1995) Antioxidants and immune response in aged persons: overview of the present evidence. American Journal of Clinical Nutrition 62, Suppl., 1462S-1476S.

Miller RA (1992) Aging and immune function. International Review of Immunology 124, 890-904.

Miller RA (1996) The aging immune system: primer and prospectus. Science 273, 70-74.

Moulias R, Devillechabrolle A, Lesourd B, Proust J, Marescot MR, Doumerc S, Favre-Berrone M, Congy F \& Wang A (1985) Respective roles of immune and nutritional factors in the priming of the immune responses in the elderly. Mechanisms of Ageing and Development 31, 123-137.

Moulias R, Proust J, Wang A, Congy F, Marescot M, Devillechabrolle A, Paris-Hamelin A \& Lesourd B (1984) Age related increase in auto-antibodies. Lancet $\mathbf{i}, 1128-1129$.

Muller S, Chang HC, Ward MM, Huang JH \& Kölher H (1986) Idiotype shifts. In Aging and the Immune Responses: Cellular and Humoral Aspects, pp. 309-327 [E Goidl, editor]. New York: Marcel Dekker.

Murasko DM, Weiner P \& Kaynes D (1987) Decline in mitogen induced proliferation of lymphocytes with increasing age. Clinical and Experimental Immunology 70, 440-448.

Mysliwska J, Bryl E, Foerster J \& Mysliwski A (1998) Increase of interleukin 6 and decrease of interleukin 2 production during the ageing process are influenced by the health status. Mechanisms of Ageing and Development 100, 313-328.

Nafziger J, Bessege JP, Guillosson JJ, Damais C \& Lesourd B (1993) Decreased capacity of IL-1 production by monocytes of infected elderly patients. Aging, Immunology and Infectious Diseases 4, 25-34. 
Nagel JE, Chopra RK, Chrest FJ, McCoy MT, Schneider EL, Holbrook NJ \& Adler WH (1988) Decreased proliferation, interleukin 2 synthesis and interleukin 2 receptor expression are accompanied by decreased mRNA expression, in phytohemagglutinin-stimulated cells from elderly donors. Journal of Clinical Investigation 81, 1096-1102.

Nagelkerken L, Hertogh-Huijbregts A, Dobber R \& Dräger A (1991) Age-related changes in lymphokine production related to a decreased number of CD45Rbohi CD4+ T cells. European Journal of Immunology 21, 273-281.

Nakayama KI, Nakayama K, Negishi I, Kuida K, Louie MC, Kanagawa O, Nakauchi H \& Loh DY (1994) Requirement for CD8 beta chain in positive selection of CD8 lineage T cells. Science 263, 1131-1133.

Penn ND, Purkins L, Kelleher J, Heartley RV, Masie-Taylor BH \& Belfield PW (1991) The effect of dietary supplementation with vitamins $\mathrm{A}, \mathrm{C}$ and $\mathrm{E}$ on cell-mediated immune function in elderly long-stay patients: a randomized, controlled trial. Age and Aging 20, 169-174.

Perillo NL, Neaim F, Walford RL \& Effros RB (1993) In vitro cellular aging in T-lymphocyte cultures: analysis of DNA content and cell size. Experimental Cell Research 207, 131-135.

Prasad AS, Fitzgerald JT, Hess JW, Kaplan J, Pelen F \& Dardenne M (1993) Zinc deficiency in elderly patients. Nutrition 9, 218-224.

Proust J, Moulias R, Mumeron F, Beckkhoucha F, Bussone M, Schmid M \& Hors J (1982) HLA and longevity. Tissue Antigens 19, 168-173.

Rabinowich H, Goses Y, Reshef T \& Klajman A (1985) Interleukin 2 production and activity in aged humans. Mechanisms of Ageing and Development 32, 213-226.

Rall LC \& Meydani SN (1993) Vitamin B6 and immune competence. Nutrition Reviews 51, 217-225.

Reibnegger G, Hubber LA, Jurgens G, Schrönitzer D, Werner, ER, Watcher H, Wick G \& Traill KN (1988) Approach to define 'normal aging' in man: immune function, serum lipids, lipoproteins and neopterin. Mechanisms of Ageing and Development 46, 67-82.

Rudd AG \& Banerjeee DK (1989) Interleukin-1 production by human monocytes in ageing and disease. Age and Ageing 18, 43-46.

Sanders ME, Maggoba MW, Sharrow SE, Stephany D, Springer A, Young HA \& Shaw S (1988) Human memory T lymphocytes express increased level of three cell adhesion molecules (LFA3, CD2, and LFA1) and three other molecules (UCHL-1, CDw29, and Pgp-1) and have enhanced IFN- $\gamma$ production. Journal of Immunology 140, 1401-1407.

Shearer GM (1997) Th1/Th2 changes in aging. Mechanisms of Ageing and Development 94, 1-5.

Sindermann J, Kruse A, Frercks HJ, Schutz RM \& Kirchner H (1993) Investigations of the lymphokine system in elderly individuals. Mechanisms of Ageing and Development 70, 149-159.
Steinmann GG, Klaus B \& Muller-Hermelink HK (1985) The involution of the ageing human thymic epithelium is independent of puberty. Scandinavian Journal of Immunology 22, 563-575.

Stulning TM, Bühler E, Böck G, Kirchebner C, Schönitzer D \& Wick G (1995) Altered switch in lipid composition during T cell blast transformation in the healthy elderly. Journal of Gerontology 50A, 383-390.

Talbott MC, Miller LT \& Kerkvliet NI (1987) Pyridoxine supplementation: effect on lymphocyte responses in elderly persons. American Journal of Clinical Nutrition 46, 659-664.

Thoman ML (1997) Effects of the aged microenvironment on CD4+ T cell maturation. Mechanisms of Ageing and Development 96, 75-88.

Traill KN, Schönitzer D, Jürgens G, Böck G, Pfeilschifter R, Hilchenbach M, Holasek A, Förster O \& Wick G (1985) Age related changes in lymphocyte subset proportions, surface differentiation antigen density and plasma membrane fluidity: application of the Eurage Senieur Protocol admission criteria. Mechanisms of Ageing and Development 33, 39-66.

Tyan ML (1981) Marrow stem cells during development and aging. In Handbook of Immunology and Aging, pp. 87-102 [MMB Kay and T Makinodan, editors]. New York: CRC Press.

Utsuyama M, Kasai M, Kurashima C \& Hirokawa K (1997) Age influence on the thymic capacity to promote differentiation of $\mathrm{T}$ cells: induction of different composition of T cells subsets by aging thymus. Mechanisms of Ageing and Development 58, 167-177.

Venkatraman JT, Attwood VG, Turturro A, Hart RW \& Fernandes G (1994) Maintenance of virgin T-cells and immune functions by food restriction during aging in long-lived B6D2F1 female mice. Aging, Immunology and Infectious Diseases 5, 13-26.

Weksler ME (1995) Immune senescence: deficiency or dysregulation. Nutrition Reviews 53, S3-S7.

Welle S, Thornton C \& Jozefowicz R (1993) Myofibrillar protein synthesis in young and old men. American Journal of Physiology 264, E693-E698.

Wick G \& Grubeck-Lowenstein B (1997) Primary and secondary alterations of immune reactivity in the elderly: impact of dietary factors and disease. Immunological Reviews 160, 171-184.

Wick G, Huber LA, Xu Q, Jarosch E, Schönitzer D \& Jürgens G (1991) The decline of the immune response during aging: the role of an altered lipid metabolism. Annals of the New York Academy of Sciences 621, 277-290.

Yarasheski KE, Zachwieja JJ \& Bier DM (1993) Acute effects of resistance exercise on muscle protein synthesis rate in young and elderly men and women. American Journal of Physiology 265, E210-E214.

Yong-Xing M, Yue Z, Zan-Shun W, Chuan-Fu W, Su-Ying C, Mao-Tong Z, Gong-Liang Z, Su-Qin Z, Jian-Gang Z, Qi G \& Lin H (1997) HLA and longevity or aging among Shanghai Chinese. Mechanisms of Ageing and Development 94, 191-198. 
